\title{
THE USE OF CODE-MIXING AMONG PAMONANESE IN PARATA NDAYA CLOSED-GROUP FACEBOOK
}

\author{
Joice Yulinda Luke \\ English Laboratory Unit, Faculty of Economic and Business, Perbanas Institute \\ Jln. Perbanas, Karet Kuningan-Setiabudi, Jakarta Selatan 12940 \\ joiceyulinda@gmail.com
}

\begin{abstract}
Research intended to figure out why Pamonanes did code-mixing in Parata Ndaya, a Facebook closed-group site. The research applied qualitative method to get the types of code-mixing and reasons for doing code-mixing, while the analysis used Hoffman's theory. Data were taken from comments of three active members of Parata Ndaya. Comments selected were mainly focused on political issues that happened during Regional House Representative Election in 2014. Data analysis reveals that code-mixing is mostly found in jokes and some comments about political leaders. Thus, the results can provide insights for Parata Ndaya members to build awareness on preserving their local language (i.e. Pamona language) as well as to enhance solidarity among members of the group site.
\end{abstract}

Keywords: code-mixing, Facebook, Parata Ndaya

\begin{abstract}
ABSTRAK
Penelitian bertujuan untuk mencari tahu alasan orang Pamona melakukan campur-kode di grup tertutup Facebook, Parata Ndaya. Penelitian menggunakan metode kualitatif untuk mencari tipe serta alasan dalam melakukan campur-kode; sementara analisis data menggunakan teori Hoffman. Data penelitian diambil dari komentar tiga anggota aktif Parata Ndaya. Komentar yang dipilih terutama difokuskan pada isu politik yang terjadi selama Pemilu DPRD pada 2014. Hasil penelitian menunjukkan bahwa campur-kode kebanyakan ditemukan dalam lelucon dan beberapa komentar tentang pemimpin politik. Penelitian diharapkan dapat memberikan wawasan bagi anggota Parata Ndaya untuk membangun kesadaran melestarikan bahasa lokal mereka (yaitu bahasa Pamona) serta meningkatkan solidaritas antara anggota kelompok.
\end{abstract}

Kata kunci: campur-kode, Facebook, Parata Ndaya 


\section{INTRODUCTION}

Language is a tool of communication. It affects people's lives in different sectors. People use a language when they want to share ideas and thoughts. Because of that, a language becomes an essential tool in human's life. Without a language, a human may face difficulties when he or she has to make contact with others. Clark (1997:70) states: "language is a tool, an invention like the slide rule or the sextant, which allows us to both accomplish tasks more efficiently and to achieve them, otherwise unattainable goals." In short, language is a medium to accomplish activities in life.

In face to face or online interactions, people are required to select a code for communicating their messages with others. Sometimes people need to switch the code into other code in order to communicate with others. That's why in every communication setting, people will employ a code. Wardaugh (1986:101) defines that "a code is a system used for communicating between two or more parties used on any occasions." Generally, a code can be considered as a language. Supporting Wardaugh (1986), Stockwell (2002:8-9) adds: "a code is a symbol of nationalism that is used by people to speak or communicate in a particular language or a dialect, or register or accent or style on different occasions and for different purposes." It means people may vary in using a code or a language because of different purposes and occasions to communicate.

Similarly, online communication via Facebook requires Facebookers to select a certain code for communication. This code is usually similar to the code used by other people in the same speech community-like Facebookers of Parata Ndaya, an ethnic closed group site dedicated for people who are still living and ever lived in Tentena or Pamona (one of district towns in Poso, Central Sulawesi). The site allows its members to use a certain local language called Pamona language when they are commenting on the site's walls. However, this code or language is sometimes switched or mixed according to the addressee, the topic of discussion, and the purpose of communicating. Yet, switching the code or language depends much on the context or situations and the participants of communications. As Gumperz (1982:115) denotes, "the language of speech community can be analyzed both within the context of the language itself and also within the broader context of social behaviors". Take for example the case when two members of Parata Ndaya mixed two languages for sharing their ideas as follows:

\section{A: Sensasi saja yang dicari. \\ B: 'Monco! Dorang cuma cari sensasi...hehehe' \\ (That's right! They just look for sensation... (laughing)}

The above illustration shows how the B participant, who replied the A participant, suddenly mixed his statements using a local language, that is Pamona language - a language that both participants are familiar with. Of course, the B participant has his own reason for doing code-mixing from Indonesian to Pamona. To mix the code, the ' $\mathrm{B}$ ' participant must be aware whether his interlocutor, i.e. the 'A' participant, can understand the second code or Pamona language he used. If not, communication failures would be occurred. Meanwhile, the 'A' participant needs to make sure the reason why the ' $\mathrm{B}$ ' participant did code-mixing. By knowing the reason of mixing the language, both interlocutors may achieve mutual understanding.

In Parata Ndaya a closed-group site for Pamonanese or people who ever lived in Pamona-Poso, Code-Mixing $(\mathrm{CM})$ is considered as an important communication strategy via online media. Code-mixing is a helpful communication strategy for some Parata Ndaya members, who lack of vocabularies in Pamona language, to help them communicate with other Pamonanese in the site's wall.

Based on the language phenomenon found in Parata Ndaya closed group site, this study has two aims such as: 1) discusses types of code-mixing done by Pamonanese in that closed group site; 2) investigates Pamonanese reasons of doing sorts of code-mixing in Parata Ndaya, a Facebook closed group site.

\section{Code-Mixing: Types and Reasons}

Code-Mixing is a term used in bilingualism area. Code-mixing refers to "linguistic behavior of a bilingual speaker who imports words or phrases from one of his/ her languages into the other one" (Bauer, 2010:4). Hamers and Blanc (1989) in Bi (2011:60) add that "the majority of mixings are lexical in nature and nouns are most often substituted words." Shortly, CM can be defined as the code-alternation of words or phrases from language A into language $\mathrm{B}$.

Considering that code-mixing (CM) allows the change of code, it is important to know factors that can cause CM. According to Chaer and Agustina (2010), Code-Mixing (CM) is caused by several factors such as: the speaker, the addressee, the setting, the change of situation from formal to informal, and the topic. Li (1996) quoted by Bi (2011:61) mentions that "topic like family, school, workplace, pop music, fashions, and politics are most often talked about in a code-mixing way". Thus, when a bilingual person mixes up a code, he or she probably does Code-Mixing because of factors such as addressee(s), topic discussions, and contexts.

In Parata Ndaya, a Facebook closed-group site, Code-Mixing occurs in some interesting topics of discussion, such as politics, religions, and celebrities. Members show enthusiasm to talk about sub topics like legislature candidates, political parties, pro and cons of Miss World 2013 events, and the concept of Think globally-Act locally. The comments on ParataNdaya walls usually were triggered by uploaded videos or online news from Tempo, Detik.Com, Rakyat Merdeka Online, and other online media. Overall, the facts are in line with Bhatia and Ritchie (2004) who claim "Code-Mixing can also be done because of the topic discussion."

\section{Types of Code-Mixing}

Based on the scopes of switching or junctures, Hoffman (1991) categorizes code-mixing (CM) into three types: Intra-sentential, intra-lexical, and involving a change of pronunciation. 
Intra-sentential. In this type, code-mixing occurs within a phrase, a clause, or a sentence boundary.

\section{Example 1:}

Anggota legislatif da ewa "NYARA", simbol kebebasan, kecerdasan, dan kekuatan serta punya sifat dinamis.

(Anggota legislatif ini seperti kuda: simbol kebebasan, kecerdasan, dan kekuatan serta memiliki sifat dinamis)

(The legislators like a horse: a symbol of freedom, intelligence, strength, and has dynamic personality). boundary.

Intra-lexical. This category occurs within a word

\section{Example 2:}

Saudara-saudara kita to dayak jauh lebih hebat daripada kita di Poso

(Saudara-saudara kita orang Dayakjauh lebih hebat daripada kita di Poso)

(Our brothers, Dayaknese are superior than us in Poso)

Involving a change of pronunciation. It occurs in phonological level. The changes can be found in phonological structure.

\section{Example 3:}

Io, saking saya smangat, baru sadar, te ada bank di sini

(Iya, saking saya semangat, baru sadar, tidak ada bank di sini)

(Yes, because I have new spirit, I've just realized that there's no bank here)

\section{Reasons for doing Code-Mixing}

According to Hoffman (1991), there are seven reasons of Code-mixing:

\section{Talking about a particular topic}

People often prefer to talk about a particular topic in one language than in another. They do this because they feel free to convey their thoughts and emotions by using one language that the addressee is also familiar with it. In Parata Ndaya, since not all members are familiar with Pamona language, so they sometimes mixed Pamona language with Indonesian, especially when talking about politics and religious issues. They mixed the code in order to avoid misunderstanding and conflicts.

\section{Example 4:}

Beda re'e mampokarau!... hahaha

(Tidak ada yang akan tersinggung!, hahaha)

(No one will be offended! (laughing)

\section{Quoting somebody else}

Code-Mixing for this reason happens when the interlocutor quotes famous expressions or utterances. The quotations are usually from the public figure or famous people. The interlocutor quotes someone's words to prove that the interlocutor is a modern person, who always update himself or herself with new information.
Example 5:

Harus itu! Target harus DOKTOR! Seperti orang

Pandiri bilang “ane banya sise'I, da pia wo'u. Ane banya koromu, da nce'ma wo'u”, sekali lagi ku bilang. Kamu HARUS!

(Harus itu! Target harus DOKTOR! Seperti orang Pandiri bilang "kalau bukan saat ini mau kapan

lagi, kalaupun kamu mau siapa lagi”. Sekali lagi saya bilang: Kamu HARUS!)

(You should be! Your target should be a Doctor! As someone in Pandiri said "If not now then when? If not you then who?" So once again I said: "You should be (a doctor)!"

\section{Be emphatic about something}

If someone wants to be emphatic about something when communicate using a language which is not his or her native, he or she will switch his or her second language to the first language or vice-versa, either intentionally or not. The same as in ParataNdaya site, when the member wants to express his emphatic feeling to other members, the person will switch the language from Indonesian to Pamona language.

\section{Example 6:}

Iyo Om Robby, turut berduka ungkari kami ri Bali...

(Iya Om Robby, turut berduka cita dari kami di Bali) (Yes, uncle Robby. Our deepest condolences to you from us in Bali)

\section{Interjections}

Here the interlocutor uses a short exclamation that has no grammatical value. Hoffman (1991) stated that "language switching and language mixing among bilingual or multilingual people can sometimes mark by an interjection or sentence connector."

\section{Example 7:}

Iyo to Pak Pendeta.

(Iya kan Pak pendeta)

(Yes, Father).

\section{Repetition used for clarification}

For this reason, Hoffman (1991) declared that "when a bilingual wants to clarify his/her speech so that it will be understood more by the listener, he or she can sometimes use both of the languages that he or she mastered by saying the same utterance (the utterance is said repeatedly). The repetition is not only to clarify the message, but also to emphasize the message.

\section{Example 8:}

Contoh om Tiku di Pandiri, tiap hari dari sawah, pasti dia bau tanah, pece.

(Contoh om Tiku di Pandiri, tiap hari dari sawah, dia pasti bau tanah, tanah).

(An example is uncle Tiku in Pandiri, he comes from field every day, so he must be smelt earthy)

Pece means 'tanah' or land (Eng). So, the bolded word 'pece' repeats the word 'tanah' or land. 
Intentions of clarifying the speech content for interlocutor

Hoffman (1991) said that "when a bilingual person talks to another bilingual, there will be lots of CodeSwitching and Code-Mixing occurs." In other words, the interlocutor will repeat a message in one language with the purpose of making the speech run smoothly or clarifying the ideas, so it can be understood by other interlocutors.

\section{Example 9:}

Kase kesempatan bagi kami untuk menikmati hidup di hari tua sambil bercanda dengan сисu-сисu dan urus saki asam urat, kolesterol, kekule, mata mulai buloru, mangewa, dan penyakit orang tua lainnya. (Beri kesempatan bagi kami untuk menikmati hidup di hari tua sambil bercanda dengan cucu-cucu dan mengurus penyakit seperti asam urat, kolesterol, rematik, rabun, pikun, dan penyakit orang tua lainnya)

(Give a chance for us to enjoy life in the old days while joking with our grandchildren and taking care of diseases such as uric acid, cholesterol, rheumatism, myopic, dementia, and other diseases of old people)

\section{Expressing Group Identity}

Code-Switching and Code-Mixing are strategies to express group identity because the way people communicate with their group are obviously different from the way they communicate with other people from other groups (Hoffman, 1991).

\section{Example 10:}

Iyo Om kuncanimo.. Tabea mami... (Iya Om. Saya paham. Salam hormat)

(Yes, Uncle. I understand. Yours sincerely)

Moreover, Saville-Troike (1986) adds three reasons for doing Code-mixing when having interaction with other people. The three reasons are as follows.

\section{To strengthen or soften request or command}

About this reason, Code-Mixing functions to soften a command or strengthen the request in order to sound more polite and shows the power on someone else.

\section{Real of lexical need}

Another reason an interlocutor conducts CodeMixing is because of the lack of equivalent lexicons in the interlocutor's language. To convey clear messages and avoid vague meaning, interlocutors may switch his or her language into the target language (either first or second).

\section{To exclude other people when a comment is intended for only a limited audience}

It is a fact that sometimes an interlocutor only wants to communicate with certain people. The interlocutor excludes other people by using an unknown language that nobody knows at all. By doing code-mixing, interferences in communication will be solved.

\section{METHODS}

The present study uses the qualitative method that attempts to generate detailed and valid data to figure out types and reasons for doing code-mixing in Parata Ndaya closed-group site. The respondents of this study are three active members who genuinely are Pamonese. The data were taken from Parata Ndaya Walls where the three respondents were actively adding their comments on the site walls. To clarify the reasons of Code-Mixing, the open-ended interviews were implemented to support the data. The procedures of collecting data are as follows.

Data were collected from respondents' comments on Parata Ndaya site's wall in 15-17 September 2013. The dates were selected because it was the last period for legislature candidates to register themselves to KPUD Poso. All data between the ranges of time were recorded in the form of transcriptions. Data were analyzed and classified into categories of code-mixing and non codemixing. Any non code-mixing data were taken out. The code-mixing data then were tabulated and categorized based on Hoffman's (1991) classification. The number of occurrences of each category would show the most frequent reasons as well as the least reason for undertaking Code-Mixing. Then all data were analyzed and quantified in percentages using the formula:

$$
\mathbf{P}=\mathbf{F} / \mathrm{N} \times 100 \%
$$

$\mathrm{P}=$ percentage,

$\mathrm{F}=$ frequency of words,

$\mathrm{N}=$ total of words.

\section{RESULTS AND DISCUSSION}

\section{Types of comment exchanges}

This session discusses the frequency of types of comment exchanges in Parata Ndaya walls. The data were taken from table transcriptions of three active Pamonanese members of Parata Ndaya, who commented about political issues on the close-group site's wall. The table shows that Code-Mixing would be most frequently occurred in Parata Ndaya site's wall. The results of data can be found in the following table:

Table 1 Frequency of comment-type exchanges

\begin{tabular}{cccc}
\hline No & Types of comments & Frequency & Percentages \\
\hline 1 & Code-Mixing (CM) & 47 & $72 \%$ \\
2 & $\begin{array}{l}\text { Non Code-Mixing } \\
(\mathrm{NCM})\end{array}$ & 18 & $28 \%$ \\
\hline
\end{tabular}

As can be seen in Table 1, the comment exchanges in Parata Ndaya, a Facebook closed-group site, resulted in 65 comments. Of 65 comments, 47 comments (72\%) were marked as Code-Mixing (CM) and 18 comments (28\%) were Non Code-Mixing (NCM). Surprisingly, Code-Mixing facts were found higher on Parata Ndaya site compared to Non Code-Mixing. It shows that members of Parata Ndaya likes to change the code from Pamona language to Indonesian because of the lack of Pamonese vocabularies that finally triggered the members to alter 
the words into Indonesian words, phrases, and sentences. Of course, this fact violates the rules of Parata Ndaya members to use Pamona language while commenting on the site wall.

\section{Types of Code-Mixing}

This part deals with types of Code-Mixing occurrences conveyed by Pamonanese in Parata Ndaya. The data of this result were derived from respondents' corpus transcribed data. During the last period of the district legislature election, there were 7 members actively engaged on Parata Ndaya site. However, this study only counted comments from 3 members of Parata Ndaya to be observed and analyzed because of two main reasons as follows: (1) the three active members came from Pamonanese families, so they can speak and write well using Pamona language; (2) the respondents were very active in updating status as well as putting comments on Parata Ndaya walls.

Then the results of the Code-Mixing types instances are as follows. The intra-lexical mixing is dominant in amount compared to other two types: change of pronunciation and intra-sentential. There were $45 \%$ instances of code-mixing take places in the Parata Ndaya site. In the second rank is the change of pronunciation with $32 \%$ code-mixing comments. The last is intra-sentential with a total $23 \%$ out of $72 \%$ code-mixing comments. This result proved that most members of Parata Ndaya applied Code-Mixing higher than others. The production of intralexical code-mixing can facilitate members to sustain their communication due to the limitation of vocabularies in Pamona language or Indonesian language.

Furthermore, doing code-mixing by changing pronunciation were executed in a quite high amount can signalize that several Pamona language words have similar grammatical feature and can be filled in two languages. The main differences rely on the way interlocutor say the words. On the other hand, intra-sentential is only executed in a small number, $23 \%$ out of $72 \%$ of Code-mixing occurrences. Members were not executed intra-sentential as much as intra-lexical because they were not competent enough in using Pamona language. These have resulted from the fact that most of them are not Pamonanese, so they minimize error in Pamona language by choosing a safe language, i.e. Indonesian, to express their ideas.

\section{Reasons for code-mixing in Parata Ndaya site}

To answer a big question that asks reasons for employing Code-mixing when giving comments on the site walls, the study uses seven reasons of code-mixing by Hoffman (1991:116). According to Hoffman (1991), there were seven reasons people employ code-mixing in their interaction - they are: talking about a particular topic, quoting somebody else, being emphatic about something, because of lexical words, repetition used for clarification, clarifying the speech content for the interlocutor, and expressing group identity.

The categories of reasons people do code-mixing were applied to three respondents. Three respondents of this study were chosen due to their active participations to comment on Parata Ndaya site. The detailed descriptions of the data can be found from Table 2 .
Table 2 Code-Mixing Reasons in Parata Ndaya walls

\begin{tabular}{|c|c|c|c|c|c|c|c|c|}
\hline \multirow{2}{*}{$\begin{array}{l}\text { Reasons for Code- } \\
\text { Mixing }\end{array}$} & \multicolumn{2}{|c|}{ OD } & \multicolumn{2}{|c|}{ LM } & \multicolumn{2}{|c|}{ SM } & \multirow[b]{2}{*}{ Total } & \multirow{2}{*}{$\begin{array}{c}\mathrm{T} \\
\mathrm{o} \\
\mathrm{t} \\
\mathrm{a} \\
1 \\
\%\end{array}$} \\
\hline & $\mathrm{F}$ & $\%$ & $\mathrm{~F}$ & $\%$ & F & $\%$ & & \\
\hline $\begin{array}{l}\text { Talking particular } \\
\text { topic }\end{array}$ & 1 & 2 & 0 & 0 & 4 & 9 & 5 & 11 \\
\hline $\begin{array}{l}\text { Quoting Some- } \\
\text { body else }\end{array}$ & 2 & 4 & 0 & 0 & 5 & 11 & 7 & 15 \\
\hline $\begin{array}{l}\text { Emphatic about } \\
\text { something }\end{array}$ & 3 & 6 & 2 & 4 & 3 & 6 & 8 & 16 \\
\hline Interjection & 4 & 9 & 3 & 6 & 1 & 2 & 8 & 17 \\
\hline $\begin{array}{l}\text { Repetition for } \\
\text { clarification }\end{array}$ & 4 & 9 & 1 & 2 & 1 & 2 & 6 & 13 \\
\hline $\begin{array}{l}\text { Intention of clari- } \\
\text { fying the speech } \\
\text { content }\end{array}$ & 2 & 4 & 0 & 0 & 0 & 0 & 2 & 4 \\
\hline $\begin{array}{l}\text { Expressing group } \\
\text { identity }\end{array}$ & 4 & 9 & 1 & 2 & 6 & 13 & 11 & 24 \\
\hline Total & 20 & 43 & 7 & 15 & 20 & 43 & 47 & 10 \\
\hline
\end{tabular}

Table 2 describes reasons why members of Parata Ndaya performed Code-Mixing when commenting on Parata Ndaya facebook walls. Members of Parata Ndaya did Code-Mixing for seven reasons as Hoffman (1991) proposed. Of 7 reasons, expressing group identity was found as the most frequent reason for doing code-mixing in Parata Ndaya closed-group site. There were 24\% occurrences of code-mixing utterances. In the second place was interjections, which occurred $17 \%$ out of the total code-mixing comments. The third and the fourth place were emphatic about something (17\%) and quoting somebody else (15\%). Other reasons such as Repetition for clarification and talking particular topic are in the fifth and sixth places, with $11 \%$ and $13 \%$. The least frequent reason of code-mixing found in Parata Ndaya close-group site was the intention of clarifying the speech content (4\%). Overall, all members of Parata Ndaya have their own reasons for implementing Code-Mixing while writing their comments on Parata Ndaya walls.

The higher frequency of expressing group identity such as: terima kase (thank you), bale (buddy), and tabea mami (our regards) in Parata Ndaya walls demonstrated that all Facebook users, who joined Parata Ndaya close-group, respected others very much. They cooperated with others and believed Parata Ndaya close-group site as a proper medium for bonding, mutual relationship, maintaining ethnic-group identity (Pamonanese), and preserving the regional language, Pamona language. On the other hand, the least frequent reason or intention of clarifying the speech content was only executed in small percentages (4\%) because the members had already familiar with the topic discussed in the walls. Also, the members did not have any problems with the language used; either Pamona language or Indonesian. They acquired Pamona language since they were in elementary school.

Judging from individual reasons for code-mixing in Parata Ndaya walls, it is clear that all three members of Parata Ndaya site did code-mixing for different 
functions. The first Parata Ndaya member did CM for being emphatic about something, conveying strong points through interjections, expressing group identity, and clarifying messages. Table 4.2 above indicates that this member conveyed interjections $9 \%$, repetitions for clarifications $9 \%$, expressing group identity $9 \%$, and being emphatic about something $6 \%$. Below is the illustration of Facebook users (OD) commented on the picture of legislators posted on Parata Ndaya wall:

\section{Example 11:}

DP: Manoto ketua dewan se'i ja buta maka benakita wa'a anggotanya pode tekayore tempo posidang (Memang benar! Ketua dewan ini buta, makanya dia tidak melihat kalau anggotanya tertidur pada waktu sidang)

(It is true! Chairman of the board is blind, so he does not see that members asleep at the time of trial)

\section{OD: Yang penting Nyara wawasei da ewa NYORA tempo doeloe perannya}

(Yang penting seorang pemimpin saat ini berperan seperti guru waktu dulu)

(The important thing is a leader today must play a role as a teacher in the past)

Unfortunately, the second Face-book user (LM) used Code-Mixing for the sake of expressing strong feelings and gaining attention from other Facebook users. From the table 4.2, the highest percentages of reasons doing code-mixing found in LM's data is interjections such as inserting sentence fillers or sentence connectors, $6 \%$. The lowest percentage in reasons to do code-mixing is repetition for clarification ( $2 \%$ ). These results were caused by several factors, such as: to strengthen request or gain attention from other Facebook users (i.e. by using 'jo' as sentence fillers (interjection)) and to clarify the previous point said by other Facebook users (i.e. repetition for clarification). Excerpt 2 below shows how LM responded to a previous comment on the video file about think globally but act locally posted on the Parata Ndaya wall.

\section{Example 12:}

OD: Pak Aphinus Kambodji, mungkin bisa di posting sedikit-sedikit (berseri) soalnya tidak semua warga Parata Ndaya bisa mengunduh PDF. File itu berat, $O K$ ?

(Pak Aphinus Kambodji, it's better to post the file in serial because not all Parata Ndaya members can download this PDF file. That's heavy file, OK?

LM: Om Dimba, benar om, torang te'bisa baca, soalnya cuma pake HP...maklum di rimba belantara... hehehe

(Om Dimba, benar om, kami tidak bisa baca, soalnya cuma pake HP...maklum di rimba belantara... hehehe)

(Uncle Dimba, it's true uncle. We can't read it because we only use cellular phone... and you know, we live in the jungle ...(laughing).

Finally is the third Facebook user (SM), who performed Code-Mixing for three main reasons. The first was to express group identity (13\%). The second was to quote something else (11\%), and the third was to talk about a particular topic $(9 \%)$. Of the 7 reasons, interjections and repetition for clarification were found to be the least reasons of the respondents to do code-mixing. The occurrences of these two reasons are equal in frequency ( 1 or $2 \%$ ) out of total code-mixing occurrences. The results determine that the Facebook user were very careful with her comments on the Parata Ndaya walls. The person preferred to sound polite when addressing comments on the Facebook walls. However, when the comments relate to discredit others, she chose to express them in her ethnic language (i.e. Pamona language). Moreover, she used many quotations like proverbs and metaphors to sound indirect. For example:

\section{Example 13:}

BN: Monco kojo kak, tapi kenapa kak Sesi te ba caleg dang? Siapkan diri jo buat Poso 2015

(Benar kak Sesi, tapi kenapa kak Sesi tidak menjadi caleg? Siapkan diri saja buat Poso 2015)

(That's right Sister, but why Kak Sesi did not run for district legislature candidate election? Then, prepare yourself for Poso in 2015!

SM: Bernard Ndawu, so te'ba caleg kasiang... kase kesempatan jo yang lain! Masih banyak yang lebih berkualitas dari ngana pe kaka ini, torang Tut Wuri Handayani jo!

(Bernard Ndawu, saya sudah tidak mencalonkan diri lagi, beri kesempatan yang lain saja! Masih banyak yang lebih berkualitas dari kakakmu ini, mari kita Tut Wuri Handayani (jadi pengikut) saja!)

(Bernard Ndawu, I have not run for that election again. Let others do it! There are still many qualified people than me, your sister. Let us just be a follower!

To sum up, some members of Parata Ndaya do code-mixing for several reasons. These members did code-mixing for preserving the regional language and to maintain bonds among themselves. In addition to that, the three active members out of 7 members, who were participating actively commenting on Parata Ndaya site during the last round of district legislators' campaign, designated their code-mixing into three types: intra-sentential, intra-lexical, and involve a change of pronunciations. All in all, members of Parata Ndaya site always concerned with topic discussion when addressing code-mixing.

\section{CONCLUSION}

Code-Mixing is a good strategy for communication in a bilingual community. By mixing the code, interlocutors will solve communication barriers, such as misunderstanding or misinterpretation. Furthermore, code-mixing can help interlocutors who have lack of vocabularies in their first and second language. By doing code-mixing between the two languages as Pamona language to Indonesian language or vice versa, language users are able to acquire more exposures in both languages. As a result, language death can be avoided and mutual collaboration between interlocutors can be achieved. 
Based on the results of this research, the writer has the recommendations as follows. The research findings could give inputs for bilingualism and sociolinguistics further studies that deal with code-mixing or any language alteration phenomena found in different context or situations. It is suggested that further studies can extend the focus of research in literary written works, such as: letters, drama scripts, or movie scripts.

Furthermore, it also suggested that further researches have to consider topic discussions and other social factors such as: power, age, gender, and distance that could affect or influence code-mixing facts.

It is also recommended for Facebook users, either in open or close-group site, to pay more attention to what people talk about in order to avoid misunderstanding with other Facebook users who probably are not familiar with certain vocabularies of a particular language.

The study also suggests that all members of Parata Ndaya closed-group site to accustom to Pamona language when sharing ideas in the walls. Those members who like to use Pamona language should be concise when writing the language words on the wall. Avoid abbreviating words when writing comments on the wall.

\section{REFERENCES}

Bauer, R. S. (2010). Code-switching and Code-mixing. LING6014: History and Structure of Cantonese. Retrieved from http://www.linguistics.hku.hk/ cou/adv/ling6014/2010/LING6014 Lecture 8 Code Switching Mixing for Students 13112010.pdf

Bhatia, T. K., \& Ritchie, W. C. (2004). Social and psychological factors in language mixing. In W. C. Ritchie \& T. K. Bhatia (Eds.), Handbook of Bilingualism (pp. 336-352). Blackwell Publishing.

Bi, N. Z. (2011). An investigation into English mixing in Chinese Internet language. World Journal of English Language, 1(2), 60-67. http://doi. org/10.5430/wjel.v1n2p60

Chaer, A., \& Agustina, L. (2010). Sosiolinguistik: Perkenalan awal (Revisi). Jakarta: Rineka Cipta.

Clark, A. (1997). Being There: Putting Brain Body and World Together Again. Cambridge, Massachusetts: MIT Press. http://doi.org/10.2307/2998391

Gumperz, J. J. (Ed.). (1982). Language and Social Identity. Cambridge: Cambridge University Press.

Hamers, J. F., \& Blanc, M. H. A. (1989). Bilinguality and Bilingualism. Cambridge: Cambridge University Press.

Hoffman, C. (1991). An Introduction to Bilingualism. New York: Longman.

Li, D. C. S. (1996). Issues in bilingualism and biculturalism: A Hongkong case study. New York: Peter Lang Publishing.

Saville-Troike, M. (1986). The Ethnography of Communication: Language in society. Oxford: Blackwell.

Stockwell, P. (2002). Sociolinguistics: A resource book for students. London: Routledge.

Wardaugh, R. (1986). An Introduction to Sociolinguistics. Oxford: Basil Blackwell.

\section{APPENDIX}

Open-ended Interview Questions:

1. Which language do you often use for writing comments on Parata Ndaya wall?
a. Indonesian
b. Pamona language

2. Referring to your answer in No.1, why!

3. For what reasons do you mix your languages (Indonesian and Pamona) when writing comments on Parata Ndaya wall?

4. When did you learn Pamona language?

5. Does code-mixing help you to express your ideas?

6. Are there any negative sides of doing codemixing in Parata Ndaya wall?

Additional Questions for Administrator Parata Ndaya:

7. Do you think other members of Parata Ndaya do code-mixing because of lack of vocabularies in one of language they use (i.e.Pamona language or Indonesian)?

8. What is the reaction of Parata Ndaya members if its member made errors in a language they used (i.e. grammatical errors, spelling errors, etc) 